\title{
The Early Risk Warning Mechanism and Application of the Exploitation of Overseas Oil and Gas
}

\author{
Jianjun $\mathrm{Xie}^{1, \text { a }}$ \\ ${ }^{1}$ School of Economics, Sichuan University, Chengdu, Sichuan Province, China \\ a2289923524@qq.com
}

Keywords: Oil And Gas Resources; Risk; Early Warning.

\begin{abstract}
Oil and gas resources are the important constrains of China's economic development. The research about the risk status of oil and gas resources has important practical significance for the national economy development. Based on the view of the exploitation of overseas oil and gas resources, this paper constructs the risk early warning system of oil and gas resources, uses the method of multistage fuzzy comprehensive evaluation to build the risk early warning model, and analyzes the risk situation of petroleum and natural gas.
\end{abstract}

\section{Introduction}

The investment on overseas oil and gas resources and the establishment of overseas oil and gas production base are the needs of China's economic and social development, and the only route for our national oil and gas companies to achieve transnational operation, and to take part in the international competition. They need to realize transnational operation by the means of marketization, to exploit overseas oil and gas resources, and to solve the crisis of oil and gas security in our country. Oil and gas belong to a country's strategic resources. The supply of oil and gas is related to the economic development of countries and regions, and it can affect the stability and development of world politics and military affairs. The safety of oil and gas is an indispensable part in our national economic security system, and it has great significance to a country's national economic development. Therefore, it is very necessary to build an overseas oil and gas resources exploitation warning mechanism which is suitable to China's actual conditions.

\section{Literature Review}

Scholars have been widely discussed about the warning mechanisms of energy security. In 2009, Changcheng Zhao et al established a warning index system which could reflect China's energy security status. This system was consisted of three subsystems: coal, oil and natural gas. The researchers used principal component analysis to realize the dimensionality reduction of warning indexes, and used the method of BP neural network warning to analyze China's energy security status from the year 1995 to 2007. They proposed that the energy security level of our country was declining, and its outlook was not good. Chunjie Chi broke the traditional warning mechanisms in 2006. He improved the BP neural network method and applied it into the building of China's energy security warning system. He analyzed China's energy security status in 2010 from the perspective of common-sense warning, and put forward that in the future, China's energy security would be a big issue. We must actively respond to these questions and take actions as early as possible. In 2007, Qiang Liu et al argued that it was necessary for China to establish an energy security warning system, in order to provide cover for stable, reliable, safe, clean and economic energy supply in our country. The key to energy security warning system was to build the warning index system, and they emphatically introduced their research achievements on the warning index system. In 2008, after summarizing researches on energy security warning system, Xi Wan provided a logical thinking on the warning mechanism of natural gas supply security. Through the discussions of warning index system, warning lines determination, data processing procedure and warning signal system, Wan preliminary established the warning mechanism of China's natural gas supply security. Yanna Zhao et 
al. analyzed influence factors of China's energy security, and built the energy security warning mechanism from the perspectives of energy supply and demand, energy prices and energy use in 2010. In 2011, based on related theories and methods of complex system, Qiang Zhang built a complex giant system on energy security and exploitation. This system includes several subsystems like energy suppliers, energy consumers, the influence of economic environment, the influence of social environment, the influence of ecological environmental and safety regulation. He also used the research methods of integrated complex system to build a energy security warning system.

These papers have detailed discussed China's energy security warning mechanism. But most of these existing research fruits focus on China's own energy structure. This article is trying to construct and apply the warning mechanism from the aspect of China's overseas oil and gas resources exploitation.

\section{The Construction of Warning Index System}

Researches on China's overseas oil and gas resources exploitation means to analyze the influence factors and predict the development trends of overseas oil and gas resources exploitation, and to find out these unstable operation status and abnormal factors. Its essence is to predict the future development of overseas oil and gas resources exploitation through the correct evaluation of its current operation status. It needs to find out these irrational, abnormal phenomena in advance, and give out warning instructions timely. Building a scientific warning system is necessary to realize the early warning of overseas oil and gas resources exploitation.

The security of oil and gas resource is a comprehensive and complex issue. Many factors, such as the economic factors, political factors, diplomatic factors, military factors and resources factors, can affect its status. The warning index system of overseas oil and gas resources, therefore, is related to many warning indicators. After the analyses of internationally accepted indicators, related historical data and current situation, this paper builds up a risk warning index system for the exploitation of overseas oil and gas resources. This system uses warning indexes from four perspectives: oil and gas resources warning index, oil and gas supply and demand warning index, warning index about oil and gas imports and warning index about oil and gas markets. These indexes, together with the 9 risk levels ( shown in table 1), are used to evaluate the risk of oil and gas resources exploitation.

Table 1 warning index system for the exploitation of overseas oil and gas

\begin{tabular}{|c|c|c|}
\hline \multirow{9}{*}{$\begin{array}{l}\text { Warning Index } \\
\text { system } \\
\text { for the } \\
\text { exploitation of } \\
\text { oil and gas }\end{array}$} & \multirow{2}{*}{$\begin{array}{c}\text { warning index } \\
\text { about oil and gas resources }\end{array}$} & proven oil and gas reserves \\
\hline & & reserve and production ratio of oil and gas \\
\hline & \multirow{3}{*}{$\begin{array}{l}\text { warning index } \\
\text { about the supply and demand of } \\
\text { oil and gas }\end{array}$} & consumption increase rate of oil and gas \\
\hline & & consumption increase flexibility of oil and gas \\
\hline & & $\begin{array}{l}\text { ratio of industrial production growth } \\
\text { and consumption growth in oil and gas }\end{array}$ \\
\hline & \multirow{2}{*}{$\begin{array}{l}\text { warning index } \\
\text { about oil and gas imports }\end{array}$} & $\begin{array}{c}\text { degree of foreign dependence on } \\
\text { oil and gas }\end{array}$ \\
\hline & & concentration ratio of oil and gas import \\
\hline & \multirow{2}{*}{$\begin{array}{c}\text { warning index } \\
\text { about oil and gas market }\end{array}$} & The prices of oil and gas \\
\hline & & Price Volatility of oil and gas \\
\hline
\end{tabular}

\section{The Partition of Warning Line}

Firstly, determining the warning levels. This paper employs the nine scale method proposed by T.L.Saaty, the American operations researcher who put forward to the analytic hierarchy process. According to the risks of overseas oil and gas resources exploitation, evaluation indexes are divided into five levels (shown in table 1): no risk, low risk, moderate risk, high risk and extreme risk; they also can be shown as level V, levelIV, levelIII, level II and level I . The higher of the score, the greater of the risk; the lower of the score, the smaller of the risk. 
Table 2 score table on the risk level of oil and gas resources

\begin{tabular}{|c|c|c|c|c|c|}
\hline $\begin{array}{c}\text { Evaluation of } \\
\text { risk level }\end{array}$ & $\begin{array}{c}\text { Level V } \\
\text { no risk }\end{array}$ & $\begin{array}{c}\text { Level IV } \\
\text { Low risk }\end{array}$ & $\begin{array}{c}\text { Level III } \\
\text { moderate risk }\end{array}$ & $\begin{array}{c}\text { Level II } \\
\text { High risk }\end{array}$ & $\begin{array}{c}\text { LevelI } \\
\text { Extreme risk }\end{array}$ \\
\hline sore & 1 & 3 & 5 & 7 & 9 \\
\hline
\end{tabular}

Secondly, determining the evaluation standards of warning indexes. This article determines the evaluation standards of warning indexes after comprehensive comparisons of existing research materials, as well as detailed analyses of economic development patterns and development status of oil and gas industry. This method uses part of Dr. Qiufang Fan's idea as reference [1]. The warning indexes are also divided into five levels. Due to the relatively large difference between oil and gas resources factors, the evaluation of warning indexes of these two subsystems are carried out respectively

Table 3 evaluation standard of warning indexes

\begin{tabular}{|c|c|c|c|c|c|c|c|}
\hline \multirow{4}{*}{$\begin{array}{l}\text { evalu- } \\
\text { ation } \\
\text { system }\end{array}$} & \multirow{4}{*}{ types of evaluation } & \multirow{4}{*}{ evaluation index } & \multicolumn{5}{|c|}{ level and score } \\
\hline & & & levelV & levelIV & Level III & levelII & levelI \\
\hline & & & $\begin{array}{l}\text { No } \\
\text { risk }\end{array}$ & $\begin{array}{l}\text { Low } \\
\text { risk }\end{array}$ & $\begin{array}{l}\text { Moderate } \\
\text { risk }\end{array}$ & $\begin{array}{l}\text { High } \\
\text { risk }\end{array}$ & $\begin{array}{l}\text { Extreme } \\
\text { risk }\end{array}$ \\
\hline & & & 1 & 3 & 5 & 7 & 9 \\
\hline \multirow{9}{*}{$\begin{array}{c}\text { Oil } \\
\text { sub- } \\
\text { system }\end{array}$} & \multirow{2}{*}{$\begin{array}{l}\text { Oil } \\
\text { resources } \\
\text { factors }\end{array}$} & $\begin{array}{l}\text { proven reserves } \\
\text { [billion barrels] }\end{array}$ & $>400$ & $\begin{array}{c}250 \sim \\
400\end{array}$ & $150 \sim 250$ & $\begin{array}{l}50 \sim \\
150\end{array}$ & $0 \sim 50$ \\
\hline & & $\begin{array}{l}\text { reserve and production } \\
\text { ratio [year] }\end{array}$ & $>40$ & $25 \sim 40$ & $12 \sim 25$ & $5 \sim 12$ & $0 \sim 5$ \\
\hline & \multirow{3}{*}{$\begin{array}{l}\text { Oil } \\
\text { supply } \\
\text { factors }\end{array}$} & $\begin{array}{c}\text { consumption increase } \\
\text { rate [\%] }\end{array}$ & $<0$ & $0 \sim 6$ & $6 \sim 8$ & $8 \sim 16$ & $>16$ \\
\hline & & $\begin{array}{l}\text { consumption increase } \\
\text { flexibility }\end{array}$ & $<0.2$ & $\begin{array}{l}0.2 \sim \\
0.4\end{array}$ & $0.4 \sim 0.6$ & $\begin{array}{c}0.6 \sim \\
0.8\end{array}$ & $>0.8$ \\
\hline & & $\begin{array}{l}\text { ratio of production growth } \\
\text { and consumption growth }\end{array}$ & $>0.7$ & $\begin{array}{c}0.5 \sim \\
0.7\end{array}$ & $0.3 \sim 0.5$ & $\begin{array}{c}0.1 \sim \\
0.3\end{array}$ & $<0.1$ \\
\hline & \multirow{2}{*}{$\begin{array}{l}\text { Oil } \\
\text { imports of factors }\end{array}$} & $\begin{array}{c}\text { degree of foreign } \\
\text { dependence }\end{array}$ & $0 \sim 10$ & $10 \sim 29$ & 29〜31 & $\begin{array}{l}31 \sim \\
60\end{array}$ & $>60$ \\
\hline & & Import concentration ratio & $0 \sim 20$ & $20 \sim 48$ & $48 \sim 52$ & $\begin{array}{l}52 \sim \\
80\end{array}$ & $80 \sim 100$ \\
\hline & \multirow{2}{*}{ Oil market factors } & $\begin{array}{c}\text { Price } \\
\text { [dollar per barrel] }\end{array}$ & $<20$ & $20 \sim 33$ & $33 \sim 37$ & $\begin{array}{c}37 \sim \\
80\end{array}$ & $>80$ \\
\hline & & Price Volatility [\%] & $<0$ & $0 \sim 30$ & $30 \sim 40$ & $\begin{array}{l}40 \sim \\
80\end{array}$ & $>80$ \\
\hline \multirow{5}{*}{$\begin{array}{c}\text { Gas } \\
\text { sub- } \\
\text { system }\end{array}$} & \multirow{2}{*}{$\begin{array}{l}\text { Gas } \\
\text { resources } \\
\text { factors }\end{array}$} & $\begin{array}{c}\text { proven reserves } \\
\text { [trillion cubic meters] }\end{array}$ & $>4$ & $2.5 \sim 4$ & $1.5 \sim 2.5$ & $\begin{array}{c}0.5 \sim \\
1.5\end{array}$ & $0 \sim 0.5$ \\
\hline & & $\begin{array}{l}\text { reserve and production } \\
\text { ratio [year] }\end{array}$ & $>40$ & $25 \sim 40$ & $15 \sim 25$ & $5 \sim 15$ & $0 \sim 5$ \\
\hline & \multirow{3}{*}{$\begin{array}{l}\text { Gas } \\
\text { supply } \\
\text { factors }\end{array}$} & $\begin{array}{c}\text { consumption increase } \\
\text { rate [\%] }\end{array}$ & $<0$ & $0 \sim 12$ & $12 \sim 20$ & $\begin{array}{c}20 \sim \\
30\end{array}$ & $>30$ \\
\hline & & $\begin{array}{c}\text { consumption increase } \\
\text { flexibility } \\
\end{array}$ & $<1$ & $1 \sim 1.2$ & $1.2 \sim 1.4$ & $\begin{array}{c}1.4 \sim \\
1.6\end{array}$ & $>1.6$ \\
\hline & & $\begin{array}{l}\text { ratio of production growth } \\
\text { and consumption growth }\end{array}$ & $>0.9$ & $\begin{array}{l}0.8 \sim \\
0.9\end{array}$ & $0.6 \sim 0.8$ & $\begin{array}{c}0.6 \sim \\
0.4\end{array}$ & $<0.4$ \\
\hline
\end{tabular}




\begin{tabular}{|c|c|c|c|c|c|c|}
\multirow{4}{*}{$\begin{array}{c}\text { Gas } \\
\text { imports of factors }\end{array}$} & $\begin{array}{c}\text { degree of foreign } \\
\text { dependence }\end{array}$ & $0 \sim 10$ & $10 \sim 29$ & $29 \sim 31$ & $\begin{array}{c}31 \sim \\
60\end{array}$ & $>60$ \\
\cline { 2 - 7 } & Import concentration ratio & $0 \sim 20$ & $20 \sim 48$ & $48 \sim 52$ & $\begin{array}{c}52 \sim \\
80\end{array}$ & $80 \sim 100$ \\
\hline \multirow{2}{*}{$\begin{array}{c}\text { Gas } \\
\text { market factors }\end{array}$} & $\begin{array}{c}\text { Price } \\
\text { [dollar per million BTU] }\end{array}$ & $<2$ & $2 \sim 3.3$ & $3.3 \sim 3.7$ & $3.7 \sim 8$ & $>8$ \\
\cline { 2 - 7 } & Price Volatility [\%] & $<0$ & $0 \sim 40$ & $40 \sim 50$ & $\begin{array}{c}50 \sim \\
80\end{array}$ & $>80$ \\
\hline
\end{tabular}

\section{Assessment and Application of Warning Evaluation System}

Risk assessment means, by using warning index system, researches can select appropriate methods and models to compare the monitoring data with warning lines. A warning evaluation model is needed in evaluation. The evaluation result is the output of this model. Many complex factors influence our overseas oil and gas resources exploitation, which causes the fuzziness of evaluation objects description. Thus, the fuzzy mathematic theory is applied in the research. Using the fuzzy comprehensive evaluation method to deal with the data can make the evaluation results more reasonable. By reference to domestic and foreign existing research results, this paper uses the multi-level fuzzy synthetic evaluation model which combines analytic hierarchy process as the assessment tool.

Comprehensive evaluation is a mathematical tool to make comprehensive decisions. If there are many factors related to the evaluation object, it will be hard to reasonably determine the weight distribution. That is, it will be difficult to truly reflect factors' positions. Under that situation, multilevel evaluation should be used [2].

First, determining the evaluation factors set $\mathrm{U}$ and evaluation results set $\mathrm{V}$. Oil and natural gas are two separate parts of oil and gas resources. Influence factors have different effects on them. Thus, it is necessary to do the risk assessment separately. According to table 3, setting up the evaluation factors set for oil and gas respectively, namely the set $U=\{U 1, U 2, U 3, U 4\}=\{$ risk of oil resources, risk of oil supply and demand, risk of oil import, risk of oil market $\}, U^{\prime}=\left\{1, U^{\prime} U ' 2,3, U^{\prime} U^{\prime} 4\right\}=\{$ risk of gas resources, risk of gas supply and demand, risk of gas import, risk of gas market $\}$, the primary evaluation factors set can be divided into several sub factors set:

$\mathrm{U} 1=\{\mathrm{r} 1, \mathrm{r} 2\}=\{$ proven oil reserves, reserve and production ratio of oil $\}$,

$\mathrm{U} 2=\{\mathrm{r} 3, \mathrm{r} 4, \mathrm{r} 5\}=\{$ consumption increase rate of oil, consumption increase flexibility of oil, ratio of production growth of oil $\}$,

$\mathrm{U} 3=\{\mathrm{r} 6, \mathrm{r} 7\}=\{$ degree of foreign dependence of oil, import concentration ratio of oil $\}$

$\mathrm{U} 4=\{\mathrm{r} 8$, and $\mathrm{r} 9\}=\{$ oil price, oil price volatility $\}$

$\mathrm{U}^{\prime} 1=\left\{\mathrm{r}^{\prime} 1, \mathrm{r}^{\prime} 2\right\}=\{$ proven gas reserves, reserve and production ratio of gas $\}$,

$\mathrm{U}^{\prime} 2=\left\{\mathrm{r}^{\prime} 3, \mathrm{r}^{\prime} 4, \mathrm{r}^{\prime} 5\right\}=\{$ consumption increase rate of gas, consumption increase flexibility of gas, ratio of production growth of gas $\}$,

$U^{\prime} 3=\left\{r^{\prime} 6, r^{\prime} 7\right\}=\{$ degree of foreign dependence of gas, import concentration ratio of gas $\}$

$\mathrm{U}^{\prime} 4=\left\{\mathrm{r}^{\prime} 8\right.$, and $\left.\mathrm{r}^{\prime} 9\right\}=\{$ gas price, gas price volatility $\}$

This paper divides the evaluation results into five levels. Comment set $\mathrm{V}=\mathrm{V}^{\prime}=\{$ no risk, low risk, moderate risk, high risk, extreme risk\}.

Second, determining the single factor evaluation matrix R. To establish the single factor evaluation matrix, reasonable value range of index should be determined first. The risk level index of China's exploitation on overseas oil and gas resources are shown in table 3.

Third, determining the membership function. Different methods can be used to determine the membership function, such as rectangular distribution and half rectangular distribution, trapezoidal distribution and half trapezoid distribution, parabolic distribution, normal distribution, Cauchy distribution and ridge shape distribution. In this paper, the fuzzy distribution adopts the commonly seen trapezoidal distribution. As the space is limited, membership functions on warning indexes about China's exploitation on overseas oil and gas resources are not discussed here. 
Fourth, the determination of weight. This paper determine the weight of ground index by using Tienan Zhang and Jinglei Li's idea. The variation coefficient method and Delphi method are used to determine the weights of each ground index, in order to reflect the degree of importance of various factors. For each index, there is a set of statistics data $x_{1}, x_{2}, \ldots x_{\mathrm{n}-1}, x_{\mathrm{n}}$,

$$
\begin{gathered}
\bar{x}=\frac{1}{n} \sum_{i=1}^{n} x_{i} \\
\sigma_{k}=\sqrt{\frac{1}{n-1} \sum_{i=1}^{n}\left(x_{i}-\bar{x}\right)^{2}}
\end{gathered}
$$

then

$$
v_{k}=\frac{\sigma_{k}}{|\bar{x}|}
$$

Is the variance coefficients of $x_{1}, x_{2}, \ldots x_{\mathrm{n}-1}, x_{\mathrm{n}}$, their weight of these coefficients

$$
\alpha_{j}=\frac{v_{j}}{\sum_{i=1}^{m} v_{i}}
$$

This article selects statistics data of ground indexes from the year 2001 to 2014, after the standardization, variation coefficient method is used to calculate their weight, and get the weight vector of these indexes. To multiply the evaluation matrix of ground indexes and their corresponding vectors, fuzzy evaluation vectors of upper index can be gotten. Through normalization, the weight of vectors of upper indicators can be gotten.

Fifth, calculating the single factor evaluation matrix. Putting the warning evaluation factor set $\mathrm{U}=$

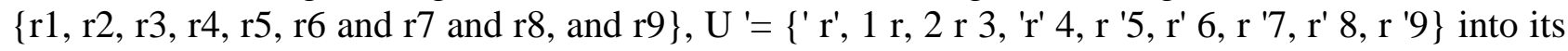
membership function to calculate, single factor evaluation results can be achieved respectively:

$\mathrm{R} 1=\{\mathrm{r} 11, \mathrm{r} 12, \mathrm{r} 13, \mathrm{r} 14, \mathrm{r} 15\}, \mathrm{r} 2=\{\mathrm{r} 21, \mathrm{r} 22, \mathrm{r} 23, \mathrm{r} 24, \mathrm{r} 25\}, \ldots, \mathrm{r} 9=\{\mathrm{r} 91 \mathrm{r} 92, \mathrm{r} 93, \mathrm{r} 94, \mathrm{r} 95\}$ and $\mathrm{r}$ ' $1=\left\{r^{\prime} 11,12, r\right.$ 'r' 13, 14, r 'r' 15 $\}, r$ '2 $=\{r$ ' 21, 22 r 'and r' 23, 24, r 'r' 25 $\}, \ldots$ ' '91,' 9 r = \{r, r '92, r' 93, r '94,' 95 r $\}$

These evaluation results are classified and arranged according to the resource risk, risk of supply and demand, import risk and market risk. Four evaluation matrixes of single index are gotten, namely:

$$
\begin{gathered}
U_{1}^{\prime}=\left[\begin{array}{l}
r_{1}^{\prime} \\
r_{2}^{\prime}
\end{array}\right]=\left[\begin{array}{l}
r_{11}^{\prime}, r_{12}^{\prime}, r_{13}^{\prime}, r_{14}^{\prime}, r_{15}^{\prime} \\
r_{21}^{\prime}, r_{22}^{\prime}, r_{23}^{\prime}, r_{24}^{\prime}, r_{25}^{\prime}
\end{array}\right] \\
U_{1}=\left[\begin{array}{l}
r_{1} \\
r_{2}
\end{array}\right]=\left[\begin{array}{l}
r_{11}, r_{12}, r_{13}, r_{14}, r_{15} \\
r_{21}, r_{22}, r_{23}, r_{24}, r_{25}
\end{array}\right]
\end{gathered}
$$

The other three evaluation matrixes of single index, namely the $U_{2}, U_{3}, U_{4}$ of oil resources and the $\mathrm{U}_{2}^{\prime} 、 \mathrm{U}_{3}^{\prime}, \mathrm{U}_{4}{ }_{4}$ of gas resources can be gotten through the same process.

Sixth, the comprehensive evaluation. The whole calculation process is carried out from bottom to top and in accordance with the hierarchy of evaluation index system. To set the single factor evaluation matrix of a index in the base layer with some element belonging to the upper or indicators or its n elements or points as 


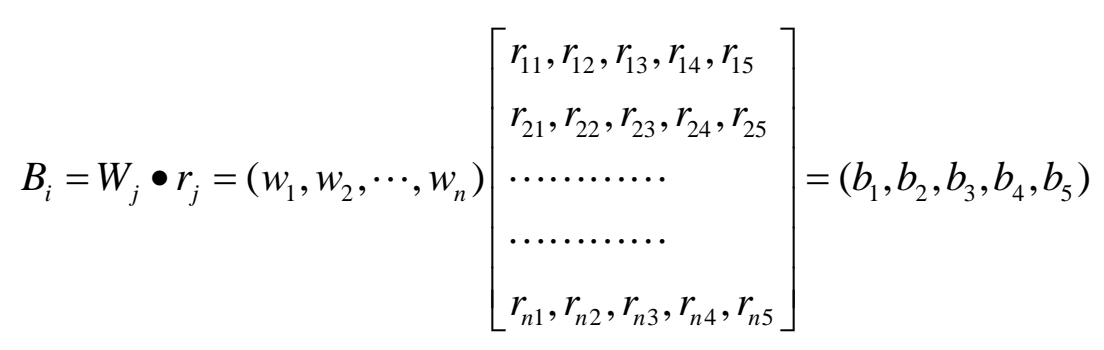

Among them, $\cdot$ adopts $(*,+)$, j represents the number of points indicators of the ith index. Then do combination to $\mathrm{Bi}$, constitute the fuzzy evaluation vectors of primary evaluation index, and multiply them with their weighting vectors, the final comprehensive evaluation results are obtained:

$$
A=W \bullet B=\left(w_{1}, w_{2}, w_{3}, w_{4}\right)\left[\begin{array}{l}
b_{11}, b_{12}, b_{13}, b_{14}, b_{15} \\
b_{21}, b_{22}, b_{23}, b_{24}, b_{25} \\
b_{31}, b_{32}, b_{33}, b_{34}, b_{35} \\
b_{41}, b_{4 n}, b_{43}, b_{44}, b_{45}
\end{array}\right]=\left(A_{2}, A_{3}, A_{4}, A_{5}\right)
$$

Do normalized processing to A, and multiply it with the evaluation set $V=(1,3,5,7,9)$, final risk value can be gotten.

Thirdly, the appliance of warning mechanism on overseas oil and gas resources exploitation

First, the determination of warning range on overseas oil and gas resources exploitation. Namely to determine the value range for different risk levels of warning system. Only in that way can we determine the risk level of our country's overseas oil and gas resources exploitation. According to the linear calibration method, the value arrange is divided into five parts. The corresponding relationship of them and the risk index $\mathrm{R}$ goes as follows: no risk $(\mathrm{R}<2)$, low risk $(2 \leq \mathrm{R}<4)$, moderate risk $(4 \leq \mathrm{R}$ $<6)$, high risk $(6 \leq \mathrm{R}<8)$, extreme risk $(\mathrm{R} \geq 8)$. Due to the difference between factors which influence the risk level of oil and gas exploitation, the risk evaluation assessments are calculated separately.

Second, making the individual test evaluation on China's overseas oil and gas resources exploitation in 2014. To bring evaluation index $r 1$ into its subordinate function, $r 1=\{0,0,0,0.065$, $0.022\}$ can be obtained. Similarly, to bring r2 into its corresponding membership function, r2 $=\{0,0,0,1,0.293\}$ can be concluded. Then assemble them into U1, the single factor matrix of oil supply and demand factors:

$$
U_{1}=\left[\begin{array}{l}
r_{1} \\
r_{2}
\end{array}\right]=\left[\begin{array}{l}
0,0,0,0.065,0.022 \\
0,0,0,1.000,0.293
\end{array}\right]
$$

According to the formula

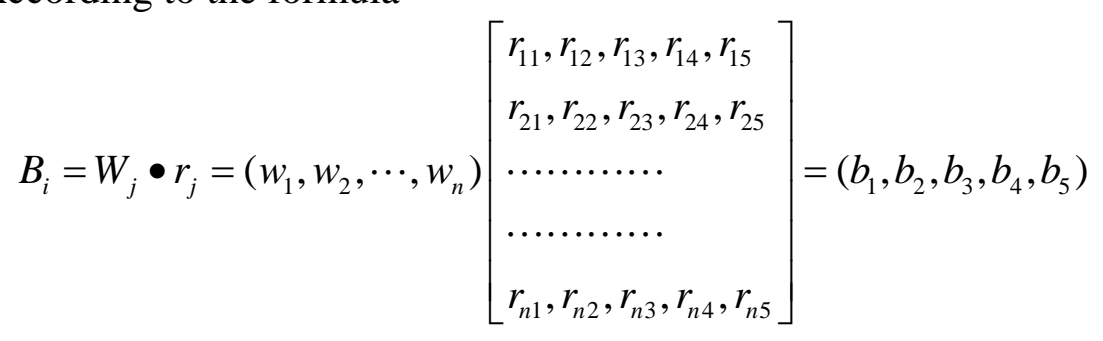

we can get

$$
B_{1}=(0.095,0.905)=\left[\begin{array}{l}
0,0,0,0.065,0.022 \\
0,0,0,1.000,0.293
\end{array}\right]=(0,0,0,0.911,0.267)
$$

similarity we can get

$$
B_{2}=(0.047,0.139,0.211,0.842,0.511), B_{3}=(0,0,0,0.542,0.391), B_{4}=(0.078,0.233,0,0 \text {, }
$$


Then put $B_{1}, B_{2}, B_{3}, B_{4}$ into the upper individual factor matrix

$$
B=\left[\begin{array}{l}
B_{1} \\
B_{2} \\
B_{3} \\
B_{4}
\end{array}\right]=\left[\begin{array}{l}
0.000,0.000,0.000,0.911,0.267 \\
0.047,0.139,0.211,0.842,0.511 \\
0.000,0.000,0.000,0.542,0.391 \\
0.078,0.233,0.000,0.000,0.267
\end{array}\right]
$$

According to the formula

$$
A=W \bullet B=\left(w_{1}, w_{2}, w_{3}, w_{4}\right)\left[\begin{array}{l}
b_{11}, b_{12}, b_{13}, b_{14}, b_{15} \\
b_{21}, b_{22}, b_{23}, b_{24}, b_{25} \\
b_{31}, b_{32}, b_{33}, b_{34}, b_{35} \\
b_{41}, b_{4 n}, b_{43}, b_{44}, b_{45}
\end{array}\right]=\left(A_{2}, A_{3}, A_{4}, A_{5}\right)
$$

Comprehensive evaluation result can be gotten

$$
\begin{aligned}
& A=W \bullet B=(0.117,0.494,0.102,0.288)\left[\begin{array}{l}
0.000,0.000,0.000,0.911,0.267 \\
0.047,0.139,0.211,0.842,0.511 \\
0.000,0.000,0.000,0.542,0.391 \\
0.078,0.233,0.000,0.000,0.267
\end{array}\right] \\
& =(0.045,0.136,0.104,0.577,0.400)
\end{aligned}
$$

Then normalize the matrix and get $A=(0.036,0.107,0.082,0.457,0.317)$

The final risk value $R=A \cdot V^{T}=6.8236862$, namely in 2014, the petroleum exploitation risk value for our country is 6.8236862 . Compared with the warning standards, we can draw the conclusion that the overall condition of oil exploitation is in high risk levels.

In the same way, we can calculate the value of natural gas exploitation risk of China 2014 is 4.390115. Compared with the warning standards, we can draw the conclusion that the overall condition of oil exploitation is in moderate risk levels.

\section{Conclusion}

Oil and gas energy are essential to the economic development of our country. This paper constructs the warning system of petroleum and natural gas by using nine indicators from four aspects, including resource factors, factors of supply and demand, the import factors and market factors. Multi-level fuzzy comprehensive evaluation is used to construct the warning model, through the analysis of application on that model, the paper shows that oil resources in China has higher level of risk, and it needs strong supervision and further development. Gas has a moderate level of risk, but it is also necessary to take measures to prevent the expanding of risks. Thus, to promote overseas oil and gas resources exploitation and strengthen risk control have great significance to ensure our energy security and to promote the healthy development of our national economy.

\section{References}

[1] Q.F.Fan, Researches on China's oil security warning and countermeasures, University of Science and Technology of China, School of Management, Hefei, 2007.

[2] L.B.Yang, Y.Y. G, The principle and application of fuzzy mathematics, South China university of technology press, Guangzhou, 2005.

[3] C.C.Zhao, Z.Y. Wang, Research on China's energy security early warning through principal component analysis and BP neural network method, J. Economic research Guide. 11(2009) 241-242. 
[4] C.J.Chi, Energy security early warning, J. Journal of statistics and decision. 11 (2006) 29-31.

[5] X.Wan, China's natural gas supply security warning research, J. Journal of natural gas technology. 3 (2008) 4-9,78.

[6] Y.N.Zhao, Y.Q.Sun, The analysis of influence factors of China's energy security and warning system, J. Journal of land and natural resources research. 2 (2010) 59-60.

[7] Q. Liu, K.X. Jiang and X.L.Hu, Warning index system design for China's energy security, J. China's energy. 4 (2007) 16-20.

[8] Q.Zhang. Energy security and early warning research based on the theory of open complex giant system, J. Science and technology forum of China. 2 (2011) 95-99.

[9] G.W.Li. Research on overseas management risk and warning mechanism of Chinese petroleum enterprise, China University of Political Science and Law, Beijing, 2009.

[10] T.N.Zhang, J.L. Li, The researches on application of multilevel fuzzy comprehensive evaluation method, J. Journal of Harbin engineering university. 6 (2002) 132-135.

[11] H. Li, Application of multilevel fuzzy comprehensive evaluation method to credit guaranteeillustrated by small and medium-sized guarantee companies in Chengdu, University of electronic science and technology, Chengdu, 2008.

[12] Z.F.Cao, China's energy security research, J. Journal of Ningxia social sciences. 5 (2004) 39-42. 